\title{
Competition, Choice and Diversity in the Newspaper Trade of the Dutch Golden Age
}

\author{
Arthur Der WeduWen
}

Arthur der Weduwen is a researcher at the University of St Andrews and the author of Dutch and Flemish Newspapers of the Seventeenth Century (2 vols., Brill, 2017). An earlier version of this work won St Andrews University's Gray prize, and the Elzevier-De Witt prize in the Netherlands. His PhD (2018) is a study of government attempts to shape public opinion in the seventeenth-century Dutch Republic, entitled Selling the Republican Ideal. State Communication in the Dutch Golden Age. His most recent book, The Bookshop of the World. Making and Trading Books in the Dutch Golden Age (co-authored with Andrew Pettegree), will appear in 2019 with Yale University Press (in English) and Atlas Contact (in Dutch).

\begin{abstract}
This article expands on the themes of choice and diversity within a national, competitive news market in the seventeenth-century Dutch Republic. It is often suggested that early newspapers largely copied one another. But that did not mean that these newspaper publishers all made the same choices, or that they adopted the same tone. Rather, they embraced and copied what they liked, and ignored what they did not. The newspaper trade in the Dutch Republic was driven by competition, innovation and diversity. The standards of what made a "good" newspaper were constantly refined during the seventeenth century. Publishers made conscious choices concerning the style, format, price and content of their papers in order to maximise their commercial potential. The diversity of titles was vital to the stimulation and later sustenance of the growing market for periodical news. News readers in the Dutch Republic were offered the greatest range of titles, complementing one another in content and style. If we look close enough at the titles available to us, we can come to a refined understanding of the early burgeoning business of news.
\end{abstract}

Keywords: newspapers, Dutch Republic, periodicity, competition, regulation, advertising, prices, Abraham Casteleyn, Gerard Lodewijk van der Macht, Adriaen Vlacq

DOI 10.18352/emlc.59 - URL: http://www.emlc-journal.org

Publisher: Stichting EMLC, supported by Utrecht University Library Open Access Journals | The Netherlands Copyright: The Author(s). This work is licensed under a Creative Commons Attribution-NonCommercial 4.0 International License. 


\title{
Competition, Choice and Diversity in the Newspaper Trade of the Dutch Golden Age
}

\author{
Arthur Der WeduWen
}

In 1674 the members of the Groningen booksellers' guild came together to regulate the sale of newspapers in the city. Out of eighteen booksellers in the city, thirteen sold newspapers. In order to limit competition amongst them, the booksellers agreed on a set price to be charged in every bookshop. ${ }^{1}$ Customers in Groningen could buy their newspaper two ways: they could either buy an issue, as one might expect, or purchase a licence to read a newspaper in a particular bookshop. In Groningen the purchase of a single issue would cost 1.5 stuivers (24 penningen). Reading in a bookshop cost half as much, three-quarters of a stuiver, or 12 penningen. Readers could also take out an annual subscription, with the option to receive one, two, three or four newspaper issues a week. Again, these could be bought or read in the bookshop only. A year's subscription for one issue cost 3 gulden and 15 stuivers; but reading in the shop was only 1 gulden and 18 stuivers. Every additional issue cost the same; it was not marginally cheaper to read more news. A year's subscription for four weekly issues of news would set one back by 15 gulden, which, if read in the bookshop, would cost 7 gulden and 10 stuivers.

The agreement between the Groningen booksellers is remarkable for three reasons. It indicates that the booksellers valued collaboration and regulation in the news trade. There was nothing like a price war to upset a market, and this was as true for textiles, peat and spices as it was for newspapers. Secondly, it makes clear that newspapers were easily and widely available far from the centre of Dutch newspaper printing. In 1674, no newspapers were printed in Groningen. The first Groningen paper would only appear seventy years later, in 1743. In 1674 the nearest paper was in fact some distance away: the only Dutch newspapers to be found were tri-weeklies in Amsterdam and Haarlem (the Amsterdamsche Courant and the Oprechte Haerlemse Courant), and a bi-weekly paper in The Hague (the Haegse Post-Tydingen); a bi-weekly Utrecht paper (the Utrechtse Courant) would be established the next year, in $1675 .{ }^{2}$ French, Italian and Spanish newspapers were also available in Amsterdam. It is possible that these papers also made their way up to Groningen, but given the absence of large Southern European 
communities in Groningen it is unlikely that these papers were ordered in large batches by the Groningen booksellers.

The regular supply of Holland newspapers in Groningen was not a unique phenomenon in the Dutch Golden Age. From the inception of the Dutch press in the early seventeenth century the first Amsterdam papers catered to a national audience. Thanks to the few archival receipts that have survived today, we know that the Amsterdam newspapers were supplied regularly to booksellers all over Holland, but also further afield to Leeuwarden and Nijmegen. ${ }^{3}$ If one looks systematically at the advertisements and announcements placed in seventeenth-century Dutch newspapers, as Andrew Pettegree and I have done as part of a study of Dutch newspaper advertising, these archival notations are reinforced. ${ }^{4}$ Already by the 1640 s Amsterdam newspapers took advertisements from booksellers all over the country, as far afield as Vlissingen, Heusden, Arnhem, Deventer, Zwolle and Groningen. The goods and services advertised in newspapers expanded in the second half of the seventeenth century; by the 1660 s municipal authorities from the eastern borders of the country would announce their forthcoming annual market in Amsterdam or Haarlem papers; and parents losing their child in rural Friesland would look to the same papers for a desperate plea. These then were papers with a wide reach: in 1734 the tri-weekly ' $s$ Graevenhaegse Courant was despatched three times a week not only to twenty-six towns in the Dutch Republic, but even abroad, to eight towns in the Southern Netherlands, three in Germany, and to London. Competing titles in Haarlem, Leiden and Amsterdam had similar destinations. ${ }^{5}$

The third notable conclusion reached from the Groningen booksellers' agreement of 1674 is that newspaper publishers and sellers in the Dutch Republic recognised that their customer base was diverse. The booksellers offered their customers choice: the fifteen gulden required for an annual subscription of four issues was a significant investment; but the twelve penningen required to read an issue in the shop allowed an altogether different class of citizen to scour the columns of a weekly paper. Newspaper readers came from different social backgrounds; they had different incomes; and different professional or personal interests. ${ }^{6}$ News writers and statesmen like Abraham de Wicquefort or Lieuwe van Aitzema, who earned their daily wage through the sale of political information, read the news regularly and attentively. Others, like the Arnhem school master David Beck, would occasionally visit the shop of the local newspaper publisher Jan Jansz to catch up on the news when he had a moment to do so. ${ }^{7}$ In the second half of the seventeenth century newspapers were also being used for reading material in schools: an instruction for the school masters of Zwolle from 1691 approved newspapers as proper classroom reading together with $\mathrm{ABC}$ books, catechisms, bibles, psalms and other devout Christian literature. ${ }^{8}$ Already

3 Borst, 'Van Hilten, Broersz. en Claessen.'; Begheyn, Abraham Leyniers.

4 Der Weduwen and Pettegree, News, Business and the Birth of Modern Advertising.

5 Noord-Hollands Archief, Haarlem, Collectie Enschedé, HBA 3523. See also Couvée, 'The administration'; Schneider and Hemels, De Nederlandse krant; Van Eeghen, 'De Amsterdamse Courant'.

6 Van Groesen, 'Reading Newspapers'.

7 Blaak, Literacy in Everyday Life; Beck, Mijn voornaamste daden; Beck, Spiegel van mijn leven.

8 Schoolordre van de stad Zwolle, rakende hare Duitse Schoolmeesteren (Zwolle: Gerrit Tydeman, [1691]). 
in 1663 the schoolmasters of Medemblik used newspapers as class material. ${ }^{9}$ Judith Brouwer, in her study of prize letters from 1672, also demonstrates persuasively that families and children from relatively humble backgrounds could obtain access to weekly papers. ${ }^{10}$

This article expands on the themes of choice and diversity within a national, competitive news market in the seventeenth-century Dutch Republic. It is often suggested that early newspapers largely copied one another; in the damaging words of the eighteenth-century historian Jan Wagenaar, to become a writer of a newspaper one required "no correspondence, no historical knowledge, no judgement, no sound mind, and not even a decent grasp of one's mother tongue". ${ }^{11}$ To Wagenaar, writing news was an activity for drones, regurgitating reports without much thought to their importance or content. In much more friendly phrasing the website of the Royal Library in The Hague states that Dutch newspapers of the seventeenth and eighteenth centuries "did not differ much in content and more or less commented on current affairs in the same manner". ${ }^{12}$ We find similar sentiments in the history of the Dutch press by Maarten Schneider, who saw no "qualitative development" in the early Dutch press between 1618 and the French Revolution. ${ }^{13}$

This is, to a certain extent, true - the function of a newspaper in the seventeenth and eighteenth centuries did not change significantly. Newspapers continued to report on international current affairs through datelined reports without substantial insight on domestic politics. And it is also true that newsmen frequently copied each other's reports. This was an element inherent to commercial news writing, but also to the competition of the trade: newspaper publishers watched each other closely. In the middle of the eighteenth century, the writers of the Amsterdamsche Courant read newspapers published in Leiden, The Hague, Haarlem, Utrecht, Cologne, Hamburg, Altona, Brussels, Paris and Madrid to inform their own content. ${ }^{14}$ But that did not mean that these newspaper publishers all made the same choices, or that they adopted the same tone. Rather, they embraced and copied what they liked, and ignored what they did not.

The newspaper trade in the Dutch Republic was driven by competition, innovation and diversity. The standards of what made a "good" newspaper were constantly refined during the seventeenth century. Publishers made conscious choices concerning the style, format, price and content of their papers in order to maximise their commercial potential. The diversity of titles was vital to the stimulation and later sustenance of the growing market for periodical news. Sometimes, as in the case of the Groningen booksellers of 1674, competition brought publishers closer together, and made formal or informal arrangements to regulate the trade. As a result, news readers in the Dutch Republic were offered the greatest range of titles, complementing one another in content and style. If we look close enough at

9 West-Fries Archief, Hoorn, Oud-Archief Stad Medemblik, 1416-1813, inv. 1266a:3 (Rekesten aan het bestuur van Medemblik).

10 Brouwer, Levenstekens, 222-226.

11 Cited in Schneider and Hemels, Nederlandse krant, 77.

12 http://www.kb.nl/organisatie/onderzoek-expertise/digitaliseringsprojecten-in-de-kb/project-databank-digitale-dagbladen/geselecteerde-titels-en-selectieprocedure/selectie-van-titels/1618-180o, Accessed 31 October 2017.

13 Schneider and Hemels, Nederlandse krant, 65. See also 46-63.

14 Van Eeghen, 'De Amsterdamse Courant', 41. 
the titles available to us, we can come to a refined understanding of the early burgeoning business of news.

\section{The Early Newspaper Market and the Inception of Diversity}

Competition was inherent to the emergence of the Dutch press. The first two weekly papers, published in Amsterdam by Caspar van Hilten and Broer Jansz, appeared as far as we can tell around the same time, in the later 1610s. Caspar van Hilten's Courante uyt Italien has the honour of being called the first Dutch newspaper, but Jansz's paper, known from 1629 as the Tijdinghen uyt verscheyde Quartieren, could well have been the first. Although we do not know of an antagonistic relationship between the two news publishers, the two men were commercial rivals, publishing similar newssheets on the same day of the week. Their co-existence was unusual in that most early newspaper publishers around Europe had the privilege of being the only newsman in town. Publishing a newspaper was expensive, and in order to protect their investments potential newsmen often petitioned for a local monopoly. At the same time, authorities realised that a single newspaper was easier to control than a multitude; the French government ensured that only one newspaper, favourable to the state, was published throughout the country. ${ }^{15}$ Not so in Amsterdam: the magistrates were happy to see both Caspar van Hilten, who was succeeded by his son Jan in the early 1620s, and Broer Jansz publish their newspapers concurrently each week on Saturdays.

The immediate appeal of the early Dutch newspaper can be established by the appearance of other newspapers in Arnhem, Delft and Utrecht, all a few years after the two Amsterdam papers first appeared. ${ }^{16}$ The Amsterdam publishers had very quickly established a standard of publication: a sober, but cost efficient double-sided half sheet folio format, with double columns of dense reports. German and English newspapers of the same time reached for the more familiar pamphlet, or newsbook style, with richer typography and white space, but using more paper. The half sheet folio became the Dutch style of publication. In the Dutch Republic it became synonymous with periodical news; and it would later serve as a model for the English press during the Restoration, as a mark of quality associated with the Dutch papers familiar to Secretary of State Joseph Williamson, responsible for the management of the London Gazette.

The Arnhem, Delft and Utrecht papers of the early 1620 s looked closely to the Amsterdam brand. And a brand it was: Jan Andriesz Cloeting, publisher of the Delft paper, called his paper the Courante uyt Italien, Duytslant ende Nederlandt, a clear imitation of Van Hilten's paper. Adriaen Leenaertsz, the publisher of the first Utrecht paper, called his the Nieuwe Courante uyt Italien, Duytslandt ende Nederlandt, echoing both Amsterdam and Delft. Cloeting especially modelled his newspaper on those of his Amsterdam colleagues. ${ }^{17}$ In his survey of the earliest Dutch newspapers, the Swedish bibliographer Folke Dahl

15 Feyel, L'Annonce et la nouvelle; Haffemayer, L'information.

16 Der Weduwen, Dutch and Flemish Newspapers, 315-325, 418-425.

17 Der Weduwen, Dutch and Flemish Newspapers, 418-422. 
suggested that Cloeting copied most of his news reports from Broer Jansz's Tijdinghen, a conclusion based on a surviving issue of the Delft newspaper dated from 10 May $1623 .{ }^{18}$ Most reports in this edition are lifted from Broer Jansz's newspaper of 8 May 1623. Cloeting published his Courante on Mondays, two days after the Amsterdam papers, allowing him to receive copies of the Amsterdam newspapers within a day of publication, and re-issuing his own version for local distribution within another day. As long as Delft customers were willing to wait two days for an improved selection of news from Amsterdam, this was a commercial strategy with potential.

Dahl was puzzled by the fact that Cloeting copied the title of his newspaper from Van Hilten's Courante, but copied his news from Broer Jansz's Tijdinghen. In fact, Cloeting's Courante was the product of a balanced selection of news reports from both Amsterdam weeklies. The earliest surviving issue from 1620 , not documented by Dahl, can be compared to Caspar van Hilten's Courante uyt Italien from Friday 21 August 1620. This demonstrates that Cloeting copied parts of the reports from Vienna, Linz and Prague directly from the Amsterdam Courante; it is likely that other reports, such as those from Leipzig, Switzerland and Cologne, were derived from the last issue of Broer Jansz's Tijdinghen from the same date, or perhaps from other sources. Cloeting's issue from 13 August 1624 is largely copied from the Tijdinghen from 10 August; the issue from 18 March 1630 takes after Van Hilten's Courante from 16 March; and the issue from 5 October 1643 is similarly copied from the Courante of 3 October. The editorial flexibility of the Delft Courante allowed Cloeting to select from both Amsterdam newspapers whichever reports he deemed most relevant and interesting; he could also supplement these with news items from his own network of pamphleteers and news writers. The survival of the Delft Courante is extremely poor, but we know that the Cloeting family was still publishing their paper in 1643: an indication that their editorial strategy had some success.

Despite the early news ventures in Arnhem, Delft and Utrecht, Amsterdam would remain the beating heart of the Dutch news trade until the 1650 s. During the 1630 s and 1640 s the Amsterdam news trade expanded rapidly. In 1635 Broer Jansz and Jan van Hilten still shared the market with a weekly issue each, but by 1645 one could find ten, perhaps eleven Dutch news issues in Amsterdam published by six different newsmen, together with two French issues (see table 1). The two older newsmen were joined by two family members of Broer Jansz, his son Joost Broersz and his son-in-law Jan Jacobsz Bouman; as well as the experienced news publisher François Lieshout, and the Frisian nobleman Mathijs van Meininga, whose Europische Courant (1642-1646) was the first tri-weekly newspaper to appear in Europe. ${ }^{19}$

By analysing the provision of news reports in these newspapers during the 1640s, it becomes clear that this expansion of the news trade was sustained because the six newsmen all cultivated varying news networks, diversifying their interests and specialisms. We see this especially in the differences between Jan van Hilten and his closest rival Broer Jansz, both of whom published on Saturdays. A comparison of surviving issues from 16361645, a period for which we have an exceptionally good rate of survival for both papers,

18 Dahl, 'Amsterdam', 191.

19 Der Weduwen, Dutch and Flemish Newspapers, 481-578. 
Table 1 Competition in the Amsterdam newspaper market. Ten Dutch issues and two French issues were published on four days of the week by six courantiers. It is also possible that the Saterdaeghsche Courante of Joost and Willemijntje Broersz was already published at this time

Newspaper publication in Amsterdam (1645)

\begin{tabular}{|c|c|c|c|c|c|c|}
\hline & Monday & Tuesday & Wednesday & Thursday & Friday & Saturday \\
\hline Jan van Hilten & $\mathrm{X}$ (French) & & & $\mathrm{X}$ & & $\mathrm{X}$ \\
\hline Broer Jansz & $\mathrm{X}$ (French) & & & & & $\mathrm{X}$ \\
\hline Joost Broersz & & $\mathrm{X}$ & & & & $\mathrm{X}$ (likely, but unconfirmed) \\
\hline Jan Bouman & $\mathrm{X}$ & & & $\mathrm{X}$ & & \\
\hline François Lieshout & & $\mathrm{X}$ & & & & \\
\hline Mathijs van Meininga & & $\mathrm{X}$ & & $\mathrm{X}$ & & $\mathrm{X}$ \\
\hline
\end{tabular}

Table 2 The top fifteen places of correspondence appearing in issues of the Courante uyt Italien and Tijdinghen uyt verscheyde Quartieren between 1636 and 1645

\begin{tabular}{llll}
\hline Top 15 places of correspondence in the Courante and the Tijdinghen (1636-1645) & Tijdinghen \\
\hline Courante & & Paris & 158 \\
\hline Cologne & 227 & Vienna & 142 \\
Antwerp & 211 & Venice & 119 \\
London & 174 & Leipzig & 117 \\
Frankfurt & 142 & Strasbourg & 114 \\
Vlissingen & 128 & Basel & 103 \\
Paris & 122 & Rome & 90 \\
Hamburg & 110 & Prague & 85 \\
Prague & 105 & Breisach & 76 \\
Bergen op Zoom & 93 & Erfurt & 67 \\
Maastricht & 83 & Milan & 52 \\
Leipzig & 81 & Cologne & 45 \\
Bremen & 78 & Nuremberg & 39 \\
Strasbourg & 75 & Franconia & 38 \\
Vienna & 71 & Dresden & 37 \\
river Rhine & 65 &
\end{tabular}

demonstrates this conjecture (see table 2). While Jan van Hilten concentrated much of his reporting on Northern Europe, on the British Isles, Northern Germany and the Baltic, Broer Jansz printed more news from Italy, France and Southern Germany, but rarely from Britain.

The two newsmen also cultivated different distribution networks. Judging by the advertisements placed in both papers during the 1630s and 1640s, booksellers from Delft, Deventer, Franeker, Gouda and Zwolle advertised only in Van Hilten's paper, while those in Alkmaar, Den Bosch and Groningen preferred Broer Jansz paper. ${ }^{20}$ Out of twenty-two Leiden booksellers who advertised in Amsterdam papers during this time, only four advertised in both papers; the rest chose one or the other. This suggests that some booksellers preferred to receive or sell on particular titles. Again, as in Groningen in 1674, sometimes competition in the trade resolved itself by distribution the market between competitors. 


\section{New Competitors and the Geographical Expansion of the Dutch Press}

In the early 1650 s the Amsterdam news trade contracted, and the magistrates of the city imposed a shared schedule of publication on the four remaining news publishers. ${ }^{21}$ Between 1654 and 1672 only two Dutch issues a week would be published in Amsterdam. This vacuum in the market immediately prompted the emergence of newspapers in other cities: in The Hague, Haarlem, Weesp, Rotterdam, Utrecht and Leiden. The first wave of new titles emerged in The Hague, and it is noteworthy that these papers deliberately abandoned the style pioneered by their Amsterdam competitors. The early The Hague newspapers appeared as quarto pamphlets of four, eight or sixteen pages, inspired by the newsbook style of publication of Paris, London and Germany. ${ }^{22}$ The publishers behind these titles, like the English royalist bookseller Samuel Browne, or the mathematician Adriaen Vlacq, had worked abroad and were familiar with these styles. But they also tried to fashion a new purpose for their publications. Vlacq advertised to his readers in 1656, when publishing the first issue of his Post-tydingen uyt 's-Gravenhage, that

For the convenience and benefit of those interested in new tidings, we have decided to circulate our post-tidings in quarto rather than in any other format, so that those who wish to gather up [the issues] will be able to bind them together at the end of the year, and keep them as a history of what has passed; even if not all will be accurate, at least it will please some curious persons... ${ }^{23}$

In order to demonstrate the suitability of his newspaper as a contemporary history, Vlacq assigned each issue a number. He also used consecutive signatures at the bottom of each issue, and a consecutive pagination statement at the top; this was a common practice of pamphlet newspapers, found all over Europe. ${ }^{24}$ But Vlacq, despite his talents as a scholar, was not a careful printer. Out of 310 surviving issues of his Post-tydingen, over 100 are misnumbered, misdated, mistitled, missigned or mispaginated - mistakes which did not do much for the reputation of Vlacq's paper, and, one can imagine, for the easy binding of issues of his paper.

The pressures of producing a bi-weekly newspaper, week in, week out, may have been a burden too much for Adriaen Vlacq. The mathematician was easily outmatched by his local rival Gerard Lodewijk van der Macht, who published a series of newspapers in The Hague in the mid-1650s. Van der Macht too departed from the Amsterdam style, adopting the pamphlet newsbook as his preferred format of publication. His newspapers were published on one or two sheets of paper, double or quadruple the size of the half-sheet Amsterdam weeklies. Van der Macht's newspapers, unsurprisingly, were also double the cost of the Amsterdam papers, sold in The Hague by local booksellers like Hendrik Hondius for two stuivers a piece. ${ }^{25}$ But for their two stuivers the readers of Van der Macht's papers received

21 Sautijn Kluit, 'De Amsterdamsche Courant', 227-228.

22 Der Weduwen, Dutch and Flemish Newspapers, 586-637, 645-670.

23 Dyns-daeghse Post-tydingen Uyt s'Graven-Haghe, vanden 4. tot den 7. Ianuary 16561 (The Hague: Adriaen Vlacq, 4 January 1656).

24 Millstone, 'Designed for Collection'; Koopmans, 'The Varying Lives'.

25 Der Weduwen, Dutch and Flemish Newspapers, 615. On Van der Macht see also Kossmann, De Boekhandel, 248-249; Kossmann, 'Haagsche uitgevers'; Keblusek, Boeken in de hofstad, 135, Sautijn Kluit, 'De 's Gravenhaagsche Courant', 13-15 and Der Weduwen, 'Fear and Loathing'. 
an extraordinary quantity of news. Van der Macht had built up an extensive network of correspondents during several years as a news writer in The Hague. While his local rival, the bi-weekly Post-tydingen of Vlacq, offered its readers around seven or eight reports each issue, Van der Macht always presented at least twenty reports. These reports were gathered from across the entire breadth of Europe; it was one of Van der Macht's trademarks to open with a report from Constantinople, followed by half a dozen other Mediterranean reports. This was a quality of news gathering which few newsmen in the Low Countries could match. If there was a region in Europe where news was to be made, Van der Macht would establish access to it and present it to his readers in the Dutch Republic. The consistency and durability of Van der Macht's news network was impressive - the fluctuations across winter and summer which one finds in other ventures do not seem to have affected Van der Macht as severely.

The quality of Van der Macht's news coverage was not only based on an efficient and widespread network of correspondents. Van der Macht was well-known to frequent the offices of state in the Binnenhof, where he maintained financial relationships with clerks and secretaries to gain access to the latest letters, memoranda and resolutions passed around the government complex. Furthermore, Van der Macht was not averse to the publication of unconfirmed rumours: most newspaper issues published by Van der Macht ended with a report from The Hague, which the courantier usually composed by stringing together half a dozen sentences of hearsay, gossip and political chatter - with little regard for their truthfulness. Van der Macht did whatever he could to present the freshest news - but he was more concerned with providing a large quantity of news, rather than evaluating its accuracy.

In his third and most successful news venture, the Haegsche Weekelycke Mercurius (II) (1655-1658), Van der Macht also experimented with a new style of newspaper publication. ${ }^{26} \mathrm{He}$ began to intersperse the regular bi-weekly issues of the Mercurius with irregular topical news pamphlets, devoted to a single news event. These irregular issues were numbered, signed and paginated in the same series as the regular newspaper issues. As a newspaper, the Haegsche Weekelycke Mercurius offered the subscriber a new reading experience: a general overview of political developments, complemented by more detailed analysis of specific events.

The single-subject issues published by Van der Macht touched on a wealth of topics. They often concerned ordinances or edicts published by foreign authorities; others took the form of letters or remonstrances exchanged between potentates or generals; or accounts of battles and lists of prisoners and casualties. On one occasion Van der Macht also devoted a topical issue to an account of a local mystery: in this case, a devilish "catdance", which was supposed to have taken place at the graveyard of the church in Katwijk, close to Leiden. ${ }^{27}$ This tale of magic and witchcraft followed an established tradition of demonological news pamphlets, but this was a subject that was not often touched upon in the periodical press. The topical issues of the Haegsche Weekelycke Mercurius varied in

26 Der Weduwen, Dutch and Flemish Newspapers, 615-637.

27 Verhael ende Waerachtige Verclaringe, Van een Wonderlijck Katten Dans, Ofte Duyvels Gespoock Geschiet inde Middernacht op het Kerck-Hof van Katwyck op Rhyn, ende daer ontrent 12 (The Hague: [Gerard Lodewijk van der Macht, 2 March 1656]). 
size: most were composed of four or eight pages, but others ran up to twenty pages. The addition of these longer pamphlets allowed Van der Macht to share with his subscribers a variety of reports and documents which would otherwise have been too lengthy to include in his regular issues, and, indeed, did not feature in the rival Amsterdam weeklies.

In April 1658, Van der Macht was banished from Holland for ten years for his inquisitive reporting practices. ${ }^{28} \mathrm{He}$ had stepped on the toes of the local regents for too long: his first two ventures in The Hague had been suspended without any further repercussions for their publisher, but this time there would be no mercy. Van der Macht fled to Utrecht, where he promptly continued his newspaper. When he arrived in Utrecht Van der Macht continued to experiment with the publishing strategies of his business. In Utrecht he published two concurrent newspapers: the bi-weekly Mercurius and, from 1659 onwards, the weekly Ordinaire Donderdaeghsche Europische Courant. ${ }^{29}$ The first appeared on Mondays and Thursdays, and was like its predecessor in The Hague interspersed with irregular topical news pamphlets.

With the Ordinaire Donderdaeghsche Europische Courant Van der Macht offered potential customers a cheaper alternative to the Mercurius. To Dutch citizens belonging to a broad middling class of artisans and professionals, a newspaper was a relative luxury. By presenting two variant publications, one appearing twice a week and marketed to the wealthier news reader, and the other to the occasional, aspiring news reader, appearing on a weekly basis, Van der Macht could broaden his market. At the same time, Van der Macht did not have to invest more capital in his network of correspondents: in the Ordinaire Donderdaeghsche Europische Courant he offered largely the same reports as in the Thursday issue of the Mercurius, but somewhat redacted. Sometimes reports from Paris, London or The Hague published in the Ordinaire Donderdaeghsche Europische Courant would date from one or two days earlier than those published in the Mercurius - Van der Macht made sure that the freshest news was saved for readers who paid for the larger, more costly pamphlet. While Van der Macht was a remarkably gifted polemicist and news gatherer, this exceptional newspaper is also evidence of his keen entrepreneurial spirit.

Van der Macht's efforts in Utrecht in the 1660s were typical of a wider variety of choice for Dutch newspaper readers during the second half of the seventeenth century. In 1666 one could have a choice between at least a dozen issues a week, published in six different towns, on every day of the week except Wednesday and Sunday. ${ }^{30}$ The norms of periodicity were changing too: until the 1640 s all Dutch newspapers had appeared as weeklies, but by the 1660 s and 1670 s bi- and tri-weekly newspapers became the norm. These changing standards had a significant impact on the financial investment required to launch a new venture. When Daniel van Gaesbeeck (1634-1693) started a newspaper in Leiden in 1686, he could not afford to do so without a significant range of correspondents. While the Amsterdam newsmen of the 1630 s opened their weekly newspapers with eight or ten reports per issue,

28 Algemeen Rijksarchief, Den Haag, archief Hof van Holland (3.03.01.01), inv. 5258.14.

29 Der Weduwen, Dutch and Flemish Newspapers, 1051-1078.

30 At least two issues in Amsterdam (Tuesday and Saturday), two issues in Haarlem (Tuesday and Saturday), two issues in The Hague (Tuesday and Friday), one issue in Weesp (Thursday), two issues in Rotterdam (Thursday and Saturday) and three issues in Utrecht (one on Monday, two on Thursday). 
Van Gaesbeeck featured at least twenty reports in his first issue, published on 30 March $1686 .{ }^{31}$ This included some twenty reports, including places as diverse as Rome, Turin, Brest, Stockholm, Copenhagen, Celle, London, and Regensburg, but also contained an apologetic note: Van Gaesbeeck implored the reader that "not all of my correspondence arrived in time for this first issue, so the reader will find that my news will soon expand and improve". ${ }^{32}$ It was essential that a courantier secured enough correspondents before he started a newspaper. The Amsterdam newsman Mathijs van Meininga was engaged in an active search for a correspondent in London months before he published his first issue. ${ }^{33}$ Joannes Naeranus in Rotterdam notified the local magistrates in his petition to start a newspaper in 1666 that he had already identified trusted correspondents in Italy, France, England and other regions. ${ }^{34}$

Van Gaesbeeck's efforts are all the more extraordinary when one considers that he was the first publisher in the Low Countries to start his newspaper as a tri-weekly. This was a serious gamble, and one which did not pay off for Van Gaesbeeck. After four months of publication he resigned as courantier, and was replaced by Lodewijck vander Saen. Other courantiers who published tri-weeklies had started with one or two weekly issues, gradually building up a solid base of subscribers. Finding enough correspondence to fill a third issue proved difficult even for the most accomplished newsmen in the market. This is best illustrated by the case of the most successful Dutch news publisher of the seventeenth century, Abraham Casteleyn. ${ }^{35}$ In 1656 Casteleyn started his first weekly paper, the Weeckelijcke Courante van Europa, soon renamed as the Oprechte Haerlemse Courant. Casteleyn was a former newsletter writer who had supplied Jan van Hilten with regular handwritten newsletters for his Courante uyt Italien. After Van Hilten's death at the end of 1655, Casteleyn decided to use his expertise as a newsman to launch his own newspaper, and he advertised the new venture in a printed handbill sent around the country to various booksellers. ${ }^{36}$

Within a decade the Oprechte Haerlemse Courant had become the country's leading paper. Already from the autumn of 1656 Casteleyn's issues were popular with advertisers spread throughout the country, a clear sign that his publicity campaign in 1656 had paid off. The 135 surviving issues of the Haarlem paper published between 1656 and 1664 contain 319 advertisements and public announcements, almost as many as the four fortnightly Amsterdam papers of the same period put together, and far more than newspapers published in The Hague and Utrecht. This is all the more remarkable given that the Amsterdam newsmen had decades to build up networks of subscribers and distributors.

Casteleyn contributed some developments which would later be taken up by rivals elsewhere in the country. Rather than print his issues in a black letter typeface, thus far the preferred design of the Amsterdam papers, from the start of his venture Casteleyn began to

31 Der Weduwen, Dutch and Flemish Newspapers, 1446-1517.

32 Ordinaris Leidse Saturdagse Courant 1 (Leiden: Daniel van Gaesbeeck, 30 March 1686).

33 Mathijs van Meininga to Samuel Hartlib, 20 January 1642, letter 37/98A-B, on M. Greengrass, M. Leslie and M. Hannon, (eds.), The Hartlib Papers (Sheffield, HRI Online Publications, 2013), accessible at http://www. hrionline.ac.uk/hartlib.

34 Der Weduwen, Dutch and Flemish Newspapers, 1116-1130.

35 On Casteleyn see especially Sautijn Kluit, 'De Haarlemsche Courant' and Peacey, 'Managing Dutch Advices', 421-437.

36 Der Weduwen, Dutch and Flemish Newpapers, 671-1050. 
experiment with the use of small roman typefaces to increase the amount of text he could fit into the columns of his paper. In order to guide the reader through the densely-packed text, Casteleyn also introduced a geographical sub-division of reports, presenting reports from Spain, Italy, France, the Holy Roman Empire, Poland and Prussia, the British Isles, and the Low Countries under separate headings. This was a distinct departure from the traditional chronological presentation of news reports in Dutch newspapers; Casteleyn popularised an organisation which allowed readers to read more selectively, focusing on specific news theatres and sources of news. Casteleyn also abandoned the practice of presenting news reports "below the line", a practice first developed by the pioneers of the Dutch news trade. ${ }^{37}$ Instead Casteleyn offered a variety of domestic reports datelined from Amsterdam, The Hague and a selection of Dutch ports.

Casteleyn's typographical experiments proved successful. Within a couple of years of publication the issues of the Oprechte Haerlemse Courant regularly contained over twenty reports per issue, and most issues were composed of close to 3,000 words. Thus far the Amsterdam papers had set the standard of publication in the Dutch Republic: from the 1630 os until the 1660 s they usually featured around 2,000-2,500 words of text and fifteen reports per issue. From the mid-166os the Amsterdam courantiers began to follow Casteleyn's lead, and Otto Barentsz Smient, Jan Jacobsz Bouman and Johannes (III) van Ravesteyn all increasingly modelled their publications on Casteleyn's paper. Casteleyn continued to stretch the limits of his newspaper: by the early 1670 s the issues of the Oprechte Haerlemse Courant were printed wholly in a small roman typeface, and most issues contained at least 3,200 words.

By 1667 the Oprechte Haerlemse Courant had achieved such success that Casteleyn decided to publish a weekly issue on Thursdays, to supplement his Tuesday and Saturday issues. Casteleyn first announced this to his readers in his paper of 24 May 1667: "for the contentment of the news-hungry reader it is my intention, now that the French, Brabant and English letters often arrive early, to publish something special, when the content merits publication; although I will retain the most remarkable news for the ordinary issues on Saturday and Tuesday. ${ }^{38}$ Casteleyn first printed a Thursday issue on 9 June 1667, entitled the Extraordinare Haerlemse Donderdaegse Courant. Casteleyn confirmed to the reader that "this is the first time that I present you with this extraordinary issue, so that you will not have to wait until Saturday ... although the most remarkable reports will be reserved for the Saturday issue." ${ }^{39}$ Casteleyn's statements and the new title might have suggested to readers that the publication of the Thursday issue was a temporary addition - but this was not the case. The Oprechte Haerlemse Courant would henceforth be a tri-weekly newspaper published on Tuesday, Thursday and Saturday.

Casteleyn maintained the title Extraordinare on the Thursday issue despite the fact that it was now a regular publication. This could be regarded as a little odd, but it may hint at a greater truth. Casteleyn was seriously testing the limits of his resources and the tastes of his customers by publishing a third issue on Thursdays. The purchase of a newspaper was, to

37 Der Weduwen, Dutch and Flemish Newspapers, 20-21.

38 Oprechte Haerlemse Dingsdaegse Courant 21 (Haarlem: Abraham Casteleyn, 24 May 1667).

39 Extraordinare Haerlemse Donderdaegse Courant 1 (Haarlem: Abraham Casteleyn, 9 June 1667). 
many readers, a relative indulgence; and initially Casteleyn struggled to fill the pages of the Thursday issue. The account books of the Oprechte Haerlemse Courant of the mid-eighteenth century reveal that the Thursday issue remained the least popular of the three: many subscribers preferred to receive only the Tuesday and Saturday issues. ${ }^{40}$

While no account books have survived for the seventeenth century, it seems that the Extraordinare Haerlemse Donderdaegse Courant was not well received by many readers in its first few years of publication. The survival of numerous typographical variants reveal that Casteleyn used two printing presses to produce the Tuesday and Saturday issue, but that he used only a single press for the Thursday issue. Furthermore, the Thursday issue was much less popular with advertisers. Between 1667 and 1677, the first ten and a half years of publication, the Thursday issues contained 465 advertisements and public announcements; during the same period the Tuesday issues contained 1,189 and the Saturday issues contained 971. By the end of the seventeenth century the Thursday issues had gained in popularity: between 1691 and 1700 they contained 2,624 advertisements and announcements, a little lower than the Tuesday $(2,840)$ and Saturday $(2,951)$ issues. Casteleyn had been too optimistic in 1667 when he launched his additional Thursday issue. His success with the other two issues, however, allowed him to persevere. Over time the Thursday issue achieved greater traction, but this was a gradual process, one which tested the means of even the most successful newspaper publisher of the Dutch Golden Age.

\section{The Importance of Credibility and Reputation in a Competitive Market}

In the second half of the seventeenth century commercial credibility and reputation came to play ever more important roles in the news market. More newspaper publishers commented on the same affairs through different sources, and, like Gerard Lodewijk van der Macht, sometimes in surprisingly different ways. The competition for customers in a busy national market led to frequent clashes between newsmen. Otto Barentsz Smient placed a lengthy note at the end of his Amsterdamsche Courant of 23 February 1673 to highlight that a report from Copenhagen placed in the Oprechte Haerlemse Courant of 7 January had not, as the Haarlem paper had contended, been written by ambassador Le Maire, but by the lord of Werkendam..$^{41}$ This was civil enough, but on occasions the need to set the record straight had a personal edge: the correction of error became an accusation of professional incompetence, or worse. In the later 1670s Abraham Casteleyn had a grudge against Broer Appelaer, publisher of the Utrechtse Courant, who was relatively new to the trade. On 27 February 1677 Casteleyn remarked in his paper that "the Utrecht courantier ... who speaks of affairs of which he knows nothing, does not merit a response". ${ }^{42}$ On 11 July 1679 he stated that "the reader should not expect an answer to the insults of the Utrecht courantier, for he does not merit an answer". ${ }^{43}$ Sadly we do not know what prompted

40 Noord-Hollands Archief, Haarlem, Collectie Enschedé, HBA 3523.

41 Amsterdamse Donderdaeghsche Courant [8] (Amsterdam: Otto Barentsz Smient, 23 February 1673).

42 Oprechte Haerlemse Saterdaegse Courant 9 (Haarlem: Abraham Casteleyn, 27 February 1677).

43 Oprechte Haerlemse Dingsdaegse Courant 28 (Haarlem: Abraham Casteleyn, 11 July 1679). 
Casteleyn to vent his anger in his way because the Utrecht issues have not survived, but it cannot have been amiable.

Another Utrecht newsman who was frequently derided by his peers was Gerard Lodewijk van der Macht. On 12 July 1659 the Amsterdam publisher Otto Barentsz Smient used up half the back of his issue in order to respond to an insult by Van der Macht in his Utrecht paper. ${ }^{44}$ Smient accused Van der Macht of publishing licentious news, and warned the regents of Utrecht that they sponsored a seditious publisher. Then Smient reprinted in its entirety the sentence handed out to Van der Macht in 1658 by the Court of Holland, to warn all his readers of the fabrications of Van der Macht. At the end Smient apologised for this unusual digression, and promised that he would publish more news next issue.

Two other newspaper publishers who stepped on each other's toes were Willem Arnold, of the Amsterdamsche Courant, and Jacob van Huysduynen, of the Opregte Leydse Courant. In 1698 Arnold published an insulting statement in his paper when Van Huysduynen managed to get hold of a despatch from Rome a day and a half before Arnold did:

While the Italian letters will be published at 10:30 this evening [in a special issue], we have read with amazement the advices from Rome of 15 November printed in the Leydse Courant of 5 December, and have not understood how the courantier [of the Leydse Courant] was able to get hold of these, except if his letters have been delivered by Pegasus, riding across the sky. ${ }^{45}$

The implication of Arnold's pointed comment, placed at the end of his newspaper, was that Van Huysduynen had fabricated the news report, rather than wait, like Arnold, for the late arrival of the letters. But Arnold received a stinging response when Van Huysduynen published his next issue, on Monday 8 December:

The German letters have not yet arrived, but those from Rome of 15 November arrived here on Thursday morning not by an imagined Pegasus, but by the ordinary post, and published later that evening: and they arrived too on Friday in Haarlem, as one finds them in the [Haarlem] newspaper of Saturday the $6^{\text {th }}$; so therefore we urge the Amsterdam courantier to find the fastest route for his letters (which pass not through the air but via roads), which seem to be completely unfamiliar to him..$^{46}$

Such public rivalry was corrosive, and dangerous for the credibility for the industry. Denouncing a competitor in the local market damaged the reputation of the trade as a whole by the suggestion that the newspapers were, in general, not to be trusted.

In these last few anecdotes emotions boiled over; generally newsmen followed the rule not to compete through insults but through their content. By the end of the seventeenth century there were four Dutch newspapers, all with a different profile and function within the news market. The leader in the market was the Oprechte Haerlemse Courant. Thanks to its decorous publisher, Abraham Casteleyn, the Haarlem tri-weekly had acquired a reputation as the paper of record in the Dutch Republic. By 1670 it was indisputably the most popular paper in the country. It had replaced the Amsterdam papers as the preferred advertising platform for the book trade. The majority of advertisements in the pages of the Oprechte Haerlemse Courant related to the publication of books or advertised book

44 Courante uyt Italien ende Duytslant, \&c. 28 (Amsterdam: Otto Barentsz Smient, 12 July 1659).

45 Amsterdamse Saturdaegse Courant 146 (Amsterdam: Willem Arnold, 6 December 1698).

46 Opregte Leydse Maandagse Courant 147 (Leiden: Jacob van Huysduynen, 8 December 1698). 
auctions - mostly taking place in Leiden, Amsterdam, and The Hague. Public announcements came in from across the country: if a child had gone missing in Groningen or Zierikzee, the best chance of finding them rested with the wide circulation of the Haarlem paper.

The advertisers of the Amsterdamsche Courant, a tri-weekly from 1673, were made up predominantly of a local clientele interested in a local audience. ${ }^{47}$ In the 168 os and 1690 s the majority of advertisements in the Amsterdam paper concerned local commercial services and auctions in the city, rather than further afield. One could find information on the sale of tobacco, sugar, ships, timber, military equipment, canaries, estates, medicinal potions and playing cards. The Amsterdamsche Courant was the newspaper of choice of the professional and merchant class of Amsterdam. On average, the Amsterdamsche Courant featured more personal announcements than its Haarlem rival: amidst the hubbub of Amsterdam, it was easy for people and possessions (ranging from watches, clothing, pets and jewellery) to go missing.

The tri-weekly Opregte Leydse Courant, published from 1686, had a very different character. ${ }^{48}$ It played a considerable role in the Dutch book trade and market for book auctions, and was popular from its inception with many booksellers throughout the country. Yet it rarely featured public announcements from beyond Leiden and its immediate vicinity. The Leiden paper could not match its Amsterdam and Haarlem rivals in its diversity of reports or its number of advertisers, but under the management of its third publisher, Jacob van Huysduynen, the Opregte Leydse Courant developed a particular specialism in reporting news from the British Isles. Van Huysduynen cultivated an extensive network of British correspondents, allowing him to follow closely the progress of Stadhouder-King William III in his campaigns against James II, and, later, the intricate politics of William's new kingdom. Van Huysduynen's British network was so detailed (and inquisitive), that in 1693 William asked the magistrates of Leiden to suspend the publication of the Opregte Leydse Courant. The regents dutifully obeyed, but six months later, when William's temper had cooled, they allowed the paper to resume publication. Thanks to his distinctive journalistic interest, Van Huysduynen's paper could appeal to a widespread, national audience.

In contrast to the Leiden newspaper, the bi-weekly Utrechtse Courant was a true local venture. ${ }^{49}$ It was unable to attract many advertisers, and the majority of those who did take advertising space resided in Utrecht itself. Its circulation was clearly more restricted than that of its rivals, and the number of reports placed in the Utrecht paper fell well below that of its competitors in the 169os. But the model of the Utrechtse Courant - that of a regional or municipal newspaper - would become ever more popular during the eighteenth century. New ventures soon emerged in The Hague, Delft, Groningen, Leeuwarden and Middelburg, to serve an audience of statesmen, civil servants, merchants and traders desiring a local paper with an advertising platform devoted largely to local commerce.

Publishing a newspaper was, and has always remained, a risky venture. Many newsmen saw their paper fold within a few years, and many failed to make a lasting impact. But the 
development of the Dutch press in the seventeenth century demonstrates that the newspaper market was not a static trade. One can identify three distinct phases of development; the early emergence of the Amsterdam papers and the development of a national market, in which rival news publishers cultivate complementing news networks; the geographical expansion of the trade, as the Amsterdam trade contracts, consensus breaks down and newsmen test the limits of periodicity; and an equilibrium, in which the intense competition and experimentation of the 1650 and 1660 s is tempered by the emergence of several tri- and bi-weekly papers with a distinct reputation in the market.

Throughout this development competition encouraged the appearance of new publication models, designs and news networks. Young entrepreneurs took over the roles of their predecessors and adapted their publishing strategies. Newspaper publishers were finely attuned to the diverse backgrounds of their customers; and the potential of their publications to appeal to new generations of newspaper readers. The collective editorial efforts of newsmen like Jan van Hilten, Broer Jansz, Jan Andriesz Cloeting, Gerard Lodewijk van der Macht and Abraham Casteleyn cultivated an ever-closer bond between commercial news media and a growing reading public. They encouraged more neophyte readers to participate in a literary world of news-reading citizens, offering them a varied but regular digest of the curiosities of their age. In the Dutch Republic, Europe's wealthiest, most crowded and dynamic society, the modern newspaper made its first steps to full-fledged maturity.

\section{Bibliography}

Beck, David, Mijn voornaamste daden en ontmoetingen. Dagboek van David Beck, Arnhem 1627-1628, ed. Jeroen Blaak (Hilversum 2014).

Beck, David, Spiegel van mijn leven. Haags dagboek 1624, ed. S.E. Veldhuijzen (Hilversum 1993).

Begheyn, Paul, Abraham Leyniers: een Nijmeegse boekverkoper uit de zeventiende eeuw (Nijmegen 1992).

Blaak, Jeroen, Literacy in Everyday Life: Reading and Writing in Early Modern Dutch Diaries, trans. Beverley Jackson (Leiden 2009).

Borst, Henk, 'Van Hilten, Broersz. en Claessen. Handel in boeken en actueel drukwerk tussen Amsterdam en Leeuwarden rond 1639', De Zeventiende Eeuw 8 (1992/1), 131-138.

Brouwer, Judith, Levenstekens. Gekaapte brieven uit het Rampjaar 1672 (Groningen 2013).

Couvée, D.H., 'The administration of the Oprechte Haerlemse Courant, 1738-1742', Gazette 4 (1958), 91-110.

Dahl, Folke, 'Amsterdam - Earliest Newspaper Centre of Western Europe', Het Boek 25 (1939/3), $161-198$.

Eeghen, I.H. van, 'De Amsterdamse Courant in de achttiende eeuw', Jaarboek van het Genootschap Amstelodamum 44 (1950), 31-58.

Feyel, Gilles, L'Annonce et la nouvelle: La presse d'information en France sous l'Ancien Régime (1630-1788) (Oxford 2000).

Groesen, Michiel van, 'Reading newspapers in the Dutch Golden Age', Media History 22 (2016/3-4), 334-352.

Haffemayer, Stéphane, L’information dans la France du Xviıe siècle: La Gazette de Renaudot de 1647 à 1663 (Paris 2002).

Keblusek, Marika, Boeken in de hofstad: Haagse boekcultuur in de Gouden Eeuw (Hilversum 1997).

Koopmans, Joop, 'The Varying Lives and Layers of Mid-Eighteenth-Century News Reports. The Example of the 1748 Peace of Aix-la-Chapelle in Dutch News Media', Media History 22 (2016/3-4), 353-370.

Kossmann, E.F., De Boekhandel te 's-Gravenhage tot het eind van de 18de eeuw (Den Haag 1937). 
Kossmann, E.F., 'Haagsche uitgevers van de zeventiende en achttiende eeuw. I. De beide Haagsche uitgevers Hendrik Hondius', Het Boek 22 (1933-34), 275-288.

Millstone, Noah, 'Designed for Collection. Early modern news and the production of history', Media History $23(2017 / 2), 177-198$.

Oomkens, J., Bouwstoffen tot eene geschiedenis van de boekdrukkunst en den boekhandel in de stad en provincie Groningen (Groningen 1854).

Peacey, Jason, 'Managing Dutch Advices. Abraham Casteleyn and the English Government, 1660-1681, Media History 22 (2016/3-4), 421-437.

Sautijn Kluit, W.P., 'De Amsterdamsche Courant', Bijdragen voor Vaderlandsche Geschiedenis en Oudheidkunde, Nieuwe Reeks, Vijfde Deel (1868), 209-292.

Sautijn Kluit, W.P., 'De 's Gravenhaagsche Courant', Jaarboek van de Maatschappij der Nederlandse Letterkunde (1875), 3-178.

Sautijn Kluit, W.P., 'De Haarlemsche Courant', Jaarboek van de Maatschappij der Nederlandse Letterkunde (1873), 3-21.

Schneider, Maarten and Joan Hemels, De Nederlandse krant 1618-1978: Van 'nieuwstydinghe' tot dagblad (Baarn $4^{\text {th }}$ ed. 1979).

Weduwen, Arthur der, Dutch and Flemish Newspapers of the Seventeenth Century, 1618-170o, 2 vols. (Leiden 2017).

Weduwen, Arthur der, 'Booksellers, newspaper advertisements and a national market for print in the seventeenth-century Dutch Republic', in Shanti Graheli (ed.), Buying and Selling. The Business of Books in Early Modern Europe (Leiden forthcoming).

Weduwen, Arthur der, 'Fear and Loathing in Weesp. Personal and political networks in the Dutch print world', in Graeme Kemp and Alexander Wilkinson (eds.), Conflict and Controversy (Leiden forthcoming).

Weduwen, Arthur der, and Andrew Pettegree, News, Business and the Birth of Modern Advertising. Advertisements and Public Announcements in Dutch and Flemish Newspapers, 1620-1675 (Leiden forthcoming). 